\title{
TGF- $\beta$ Signaling in Gastrointestinal Cancers: Progress in Basic and Clinical Research
}

\author{
Takehiko Yokobori ${ }^{1, *}$ and Masahiko Nishiyama ${ }^{1,2}$ \\ 1 Research Program for Omics-based Medical Science, Division of Integrated Oncology Research, \\ Gunma University Initiative for Advanced Research, 3-39-22 Showa-machi, Maebashi, \\ Gunma 371-8511, Japan; m.nishiyama@gunma-u.ac.jp \\ 2 Department of Molecular Pharmacology and Oncology, Gunma University Graduate School of Medicine, \\ 3-39-22 Showa-machi, Maebashi, Gunma 371-8511, Japan \\ * Correspondence: bori45@gunma-u.ac.jp; Tel.: +81-27-220-7962; Fax: +81-27-220-7963
}

Academic Editor: Andrei Turtoi

Received: 17 October 2016; Accepted: 16 January 2017; Published: 18 January 2017

\begin{abstract}
Transforming growth factor (TGF)- $\beta$ superfamily proteins have many important biological functions, including regulation of tissue differentiation, cell proliferation, and migration in both normal and cancer cells. Many studies have reported that TGF- $\beta$ signaling is associated with disease progression and therapeutic resistance in several cancers. Similarly, TGF- $\beta$-induced protein (TGFBI)—a downstream component of the TGF- $\beta$ signaling pathway-has been shown to promote and/or inhibit cancer. Here, we review the state of basic and clinical research on the roles of TGF- $\beta$ and TGFBI in gastrointestinal cancers.
\end{abstract}

Keywords: TGF- $\beta$ signaling; TGFBI; gastrointestinal cancer; EMT; tumor promoter; tumor suppressor

\section{Introduction}

Transforming growth factor (TGF)- $\beta$ signaling regulates various cellular processes including proliferation, apoptosis, differentiation, cytokine secretion, extracellular matrix (ECM) modification, and tumor migration $[1,2]$. The TGF- $\beta$ superfamily includes not only the TGF- $\beta$ ligands TGF- $\beta 1$, TGF- $\beta 2$, and TGF- $\beta 3$ but also other growth factors such as Nodal, Activin, Lefty, bone morphogenetic proteins (BMPs), and differentiation factors [3]. Upon ligand binding, TGF- $\beta$ receptors phosphorylate Smad 2 and 3. On the other hand, BMP receptors phosphorylate Smad 1, 5, and $8[2,4]$. These phosphorylated substrates translocate to the nucleus to regulate the transcription of several target genes-including cancer-associated genes such as snail, slug, and zinc finger E-box-binding homeobox (ZEB)1/2-which are known to promote epithelial-mesenchymal transition (EMT), metastasis, cancer stem cell maintenance, and angiogenesis $[5,6]$.

The TGF- $\beta$ pathway has attracted attention as both a cancer marker and therapeutic target in many diseases, including gastrointestinal cancers [6,7]. However, TGF- $\beta$ signaling plays a dual role as a tumor suppressor in pre-malignant states and as a tumor promoter in advanced cancers [2]. Therefore, there is a need for therapeutic strategies that target the TGF- $\beta$ signaling pathway, including cancer-related downstream genes without blocking the tumor-suppressor effects.

Recent advances in our understanding of TGF- $\beta$ signaling have provided insight into the molecular basis of the relationship between TGF- $\beta$ and cancer. In this review, we examine the evidence for TGF- $\beta$-induced protein (TGFBI; also known as $\beta$ ig-H3) as a therapeutic target of TGF- $\beta$ signaling in gastrointestinal cancers. TGFBI is a downstream component of the TGF- $\beta$ signaling pathway that has been implicated in corneal disorder, diabetes, and atherosclerosis as well as in the development and progression of several cancers. We also discuss the association between TGF- $\beta$ and TGFBI and their significance in gastrointestinal cancers. 


\section{Role of TGF- $\beta$ in Cancer}

TGF- $\beta$ acts as a tumor suppressor in premalignant tumor development and as a tumor promoter in advanced tumors, specifically during invasion and metastasis [8-10]. TGF- $\beta$ signaling and downstream targets are reportedly downregulated in several malignancies including lung cancer, hepatocellular carcinoma, and breast cancer [11-16]. TGF- $\beta$ signaling can induce EMT in cancer cells, which leads to metastasis [17]. EMT is an important cellular process that is associated with embryonic development, fibrosis, and tumorigenesis along with other diseases $[18,19]$. In addition to TGF- $\beta$, EMT is induced by Wnt, Notch, Hedgehog, receptor tyrosine kinases, hypoxia, and microRNAs [17]. TGF- $\beta$ pathway activation regulates E- and N-cadherin, Snail, Slug, zinc finger E-box-binding homeobox (ZEB)1, and ZEB2 $[2,18]$. Inhibiting TGF- $\beta$ signaling and thereby blocking EMT is an attractive strategy for preventing metastasis of advanced tumors.

\subsection{Significance of TGF- $\beta$ Expression in Gastrointestinal Cancers}

The high expression of TGF- $\beta$ was reported to be associated with cancer progression and metastasis in gastrointestinal cancers including esophageal cancer, gastric cancer, colon cancer, liver cancer, and pancreatic and biliary cancer [20-25]. Activation of TGF- $\beta$ signaling promotes EMT induction and maintains the cancer stem cell properties [26-28]. Moreover, the expression of TGF- $\beta$ in serum might be a useful cancer biomarker in gastrointestinal cancers $[20,22,24]$. TGF- $\beta$ signaling is identified as both of a tumor suppressor and as a tumor promoter in cancers [2], however, the evaluation of TGF- $\beta$ expression in tumor and serum is suggested to be a promising marker for poor prognosis and malignant potential in gastrointestinal cancers.

\subsection{Role of TGFBI in Cancer}

Among the downstream genes of TGF- $\beta$, TGFBI was focused as one of the candidates of EMT regulator because TGFBI expression was found to be upregulated in cholangiocarcinoma (CC) cells exhibiting mesenchymal sarcomatous changes relative to epithelial CC cells [29]. The mechanism by which TGFBI induces EMT is unclear; however, TGFBI is positively or negatively associated with cancer cell proliferation and invasion depending on the cancer type [30]. Further research is needed to clarify whether TGFBI modulates EMT in gastrointestinal cancers.

TGFBI is a $68-\mathrm{kDa}$ ECM protein that was first isolated from the A549 human lung adenocarcinoma cell line treated with TGF- $\beta$ [31]. It contains 683 amino acids that include a secretory signal peptide sequence and a cysteine-rich EMI domain as well as four fasciclin 1 motifs and an arginine-glycine-aspartate motif. TGFBI is expressed in several organs including the skin, heart, liver, and pancreas [31], and has been linked to various diseases including corneal disorder [32], diabetes [33], nephropathy [34], wound healing [35], atherosclerosis [36], and many types of cancer. In esophageal cancer, secreted-TGFBI has been detected in the ECM and tumor vasculature by immunohistochemistry [37]. TGFBI expression is regulated not only by TGF- $\beta$, but also by other mechanisms including autophagy [38,39], microRNAs [40], retinoid [41], interleukin (IL)-1 $\beta$, tumor necrosis factor- $\alpha$ [42], IL-4 [43], secreted protein acidic and rich in cysteine [44], 4-phenylbutyric acid [45], and cullin 4A [46] (Figure 1). The mechanism of TGFBI regulation merits more detailed investigation as a potential therapeutic target. 


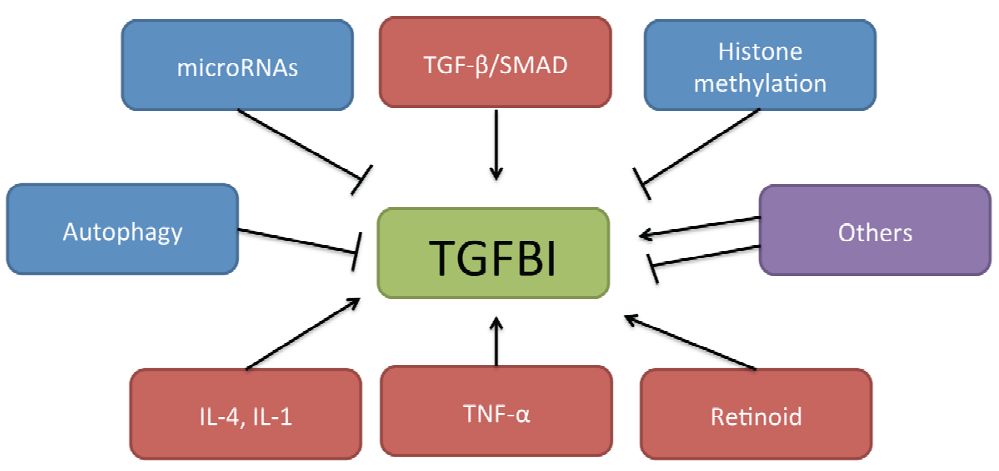

Figure 1. Mechanism of TGF- $\beta$-induced protein (TGFBI) regulation. TGFBI is regulated not only by TGF- $\beta$ /SMAD signaling but also by other mechanisms including microRNAs, histone methylation, autophagy, interleukins, tumor necrosis factor- $\alpha$, and retinoid.

\subsection{TGFBI in Gastrointestinal Cancers}

TGFBI knockout mice show increased spontaneous tumor growth and susceptibility to chemically induced skin tumors as compared to wild-type mice [47], suggesting a tumor-suppressor function. On the other hand, TGFBI has also been shown to act as a tumor promoter in the gastrointestinal tract [48], and its overexpression in mice increased the rate of formation of spontaneous gastrointestinal and $N, N$-diethylnitrosamine-induced liver tumors. However, the rate of tumorigenesis is similar between TGFBI knockout and wild-type mice. As in the case of therapeutic approaches that target TGF- $\beta$ in cancers, TGFBI inhibition may stimulate or suppress tumor growth, although several reports indicate that TGFBI promotes the growth of gastrointestinal tumors (Table 1).

Table 1. Significance of TGFBI expression in gastrointestinal tumors.

\begin{tabular}{|c|c|c|}
\hline Tumor Type & Significance & PMID Reference \\
\hline \multirow{2}{*}{ Esophageal tumor } & $\begin{array}{l}\text { TGFBI expression was higher in the extracellular matrix (ECM) of } \\
\text { tumors as compared to normal tissues. }\end{array}$ & 19082484 \\
\hline & $\begin{array}{l}\text { High TGFBI was associated with tumor progression and poor prognosis } \\
\text { in esophageal cancer. }\end{array}$ & 25448803 \\
\hline \multirow{2}{*}{ Gastric tumor } & $\begin{array}{l}\text { TGFBI overexpression in stomach tissue of TGFBI knock-in mice caused } \\
\text { gastric tumors. Serum TGFBI level was higher in gastric cancer than in } \\
\text { non-cancer patients. }\end{array}$ & 25889002 \\
\hline & $\begin{array}{l}\text { Bone-marrow-derived mesenchymal stem cells induced TGFBI } \\
\text { expression in co-cultured gastric cancer cells. }\end{array}$ & 22688186 \\
\hline \multirow{7}{*}{ Pancreatic and biliary tumor } & $\begin{array}{l}\text { Serum TGFBI expression was higher in pancreatic and biliary } \\
\text { carcinoma patients than in non-cancer patients. }\end{array}$ & 25889002 \\
\hline & $\begin{array}{l}\text { TGFBI expression in pancreas inhibited T-cell activation and production } \\
\text { of cytotoxic molecules including granzyme B and interferon- } \gamma \text { via } \\
\text { suppression of Lck tyrosine kinase. }\end{array}$ & 26470788 \\
\hline & TGFBI was overexpressed in pancreatic cancer stem cells. & 23679566 \\
\hline & $\begin{array}{l}\text { Proteomic analysis revealed that TGFBI was upregulated in pancreatic } \\
\text { cancer as compared to non-cancer tissues. }\end{array}$ & 21755970 \\
\hline & $\begin{array}{l}\text { TGF- } \beta \text { induced TGFBI mRNA expression in pancreatic cancer cells as } \\
\text { compared to normal control tissue. }\end{array}$ & 12379307 \\
\hline & $\begin{array}{l}\text { TGFBI was overexpressed in non-Opisthorchis viverrini-related } \\
\text { intrahepatic cholangiocarcinoma. }\end{array}$ & 17006947 \\
\hline & $\begin{array}{l}\text { TGFBI upregulation was associated with sarcomatous changes such as } \\
\text { EMT induction in cholangiocarcinoma. }\end{array}$ & 19287191 \\
\hline \multirow{3}{*}{ Colorectal tumor } & $\begin{array}{l}\text { TGFBI mRNA level was higher in colon cancer than in adenomas and } \\
\text { non-cancerous tissue. }\end{array}$ & 11585723 \\
\hline & $\begin{array}{l}\text { TGFBI secretion in colon cancer cells was found to be related to cancer } \\
\text { aggressiveness and extravasation. }\end{array}$ & 18245446 \\
\hline & $\begin{array}{l}\text { Stromal TGFBI expression was higher in metastatic as compared to } \\
\text { normal liver tissue. TGFBI expression was localized in the center part of } \\
\text { the metastatic area. }\end{array}$ & 23832580 \\
\hline
\end{tabular}




\subsubsection{Esophageal Cancer}

TGFBI expression was found to be upregulated in esophageal squamous cell carcinoma (ESCC) as compared to non-cancerous tissues, by microarray and reverse transcription PCR analyses. However, the significance of this observation is unclear. An examination of the relationship between TGFBI expression, clinicopathological findings, and patient prognosis revealed that TGFBI was mainly expressed in the stroma in ESCC, and patients with high stromal TGFBI expression had more frequent hematogenous recurrence and worse prognosis than those with low expression. This suggests that high levels of TGFBI in the stroma and not in tumor cells underlies tumor aggressiveness in ESCC.

\subsubsection{Gastric Cancer}

TGFBI overexpression in the ECM induced the formation of gastric tumors [48], suggesting that TGFBI has an oncogenic function in gastric cancer. Moreover, bone marrow-derived mesenchymal stem cells were shown to induce proliferation, cluster formation, and expression of the cancer stem cell marker cluster of differentiation 133 and TGFBI in co-cultured MKN7 gastric cancer cells [49]. Moreover, serum levels of secreted TGFBI were higher in gastric cancer as compared to non-cancerous patients [48]. These observations suggest that soluble TGFBI in ECM stimulates carcinogenesis and an aggressive phenotype in surrounding gastric mucosa and cancer cells.

\subsubsection{Pancreatic and Biliary Cancer}

Similar to its levels in patients with gastric cancer, serum TGFBI levels were higher in biliary carcinoma as compared to non-cancer patients [48]. Serum TGFBI concentration is therefore considered a potential biomarker in some gastrointestinal cancers; indeed, a proteomic analysis showed that TGFBI expression was higher in pancreatic ductal adenocarcinoma than in non-cancerous tissues [50].

TGFBI is downregulated in pancreatic islet cells of type 1 diabetes, and inhibits $T$ cell activation and the production of cytotoxic molecules such as granzyme B and interferon- $\gamma$ by blocking the autoimmune response via suppression of Lck tyrosine kinase [51]. TGFBI was found to be expressed in pancreatic cancer stem cells [52] and is thought to mediate immune tolerance through inhibition of cytotoxic $\mathrm{T}$ cell activation in pancreatic cancer.

TGFBI is overexpressed in non-Opisthorchis viverrini-related intrahepatic cholangiocarcinoma (CC) [53]; this is associated with sarcomatous changes such as EMT induction [29], which leads to aggressive intrahepatic spreading and metastasis in CC. As such, measurement of serum TGFBI levels may be useful for the diagnosis of EMT-induced CC with high potential for malignancy.

\subsubsection{Colorectal Cancer}

TGFBI was found to be upregulated in colorectal cancer relative to corresponding adenomas and non-cancerous tissues [54]. Expression was mainly detected in the central stroma of colon cancer that had metastasized to the liver [55]. A functional analysis of TGFBI in various colon cancer cell lines revealed that high levels of the protein were associated with enhanced metastasis and extravasation [56]. These findings suggest that TGFBI expression in colon cancer is a marker of liver metastasis.

\section{TGF- $\beta$ and TGFBI as Molecular Targets}

Clinical trials of drugs targeting the TGF- $\beta$ pathway in several diseases [57-62] have shown that directly inhibiting TGF- $\beta$ signaling can be an effective therapeutic strategy against refractory cancers, but may have severe side effects including the development of cutaneous malignancies. For instance, GC1008 - an anti-TGF- $\beta$ monoclonal antibody-induced the formation of cutaneous tumors including keratoacanthoma, squamous-cell carcinomas, and hyperkeratosis [62]. Future therapeutic approaches could target the downstream components of the TGF- $\beta$ signaling pathway to block their cancer-promoting effects without inhibiting tumor suppression. 
Overexpression of stromal TGFBI in a mouse model induced tumorigenesis of gastric mucosa and liver, but not in TGFBI knockout mice [48]. Moreover, serum TGFBI concentrations were higher in patients with cholangiocarcinoma, hepatocarcinoma, and gastric cancer than in non-tumor patients. These data suggest that TGFBI levels in the stroma, ECM, and serum may directly or indirectly promote gastrointestinal cancer development.

ECM expression of TGFBI was shown to be a useful marker for the response to paclitaxel in ovarian cancer [63]. Consistent with this observation, TGFBI was found to be a chemo-sensitizer to paclitaxel, cisplatin, and gemcitabine in lung cancer cell lines, while upregulation of TGFBI expression was associated with response to chemotherapy in lung cancer patients. Moreover, recombinant TGFBI induced apoptosis in cancer cells via integrin activation [64]. In melanoma, mesothelioma, and breast cancer, TGFBI overexpression suppressed proliferation and malignant potential [65-67]; however, targeting TGFBI may be associated with an increased risk of chemo-resistance in these patients. Further research should be performed to clarify whether TGFBI can function as a chemo-sensitizer or risk of chemo-resistance in gastrointestinal cancers.

\section{Concluding Remarks}

Dysregulation of TGFBI has been observed not only in cancers but also in corneal dystrophy and diabetes. Like TGF- $\beta$, TGFBI acts as both a tumor suppressor and promoter in several types of cancer and may be a useful therapeutic target in gastrointestinal tumors. However, the relationship between TGFBI expression and the development of chemosensitivity must be clarified since targeting TGFBI may abrogate the cytotoxic effects of chemotherapy. Combining a TGFBI inhibitor with other anticancer drugs may be an effective treatment strategy for gastrointestinal cancers that can preserve the tumor-suppressor effect of TGF- $\beta$ signaling and TGFBI.

Acknowledgments: This work was supported in part by the Promotion Plan for the Platform of Human Resource Development for Cancer and New Paradigms-Establishing Centers for Fostering Medical Researchers of the Future program funded by the Ministry of Education, Culture, Sports, Science, and Technology of Japan; and by Gunma University Initiative for Advanced Research.

Author Contributions: T.Y. and M.N. designed and wrote this work.

Conflicts of Interest: The authors declare no conflict of interest

\section{References}

1. Heldin, C.H.; Vanlandewijck, M.; Moustakas, A. Regulation of EMT by TGF $\beta$ in cancer. FEBS Lett. 2012, 586, 1959-1970. [CrossRef] [PubMed]

2. Massague, J. TGF $\beta$ signalling in context, Nature reviews. Mol. Cell Biol. 2012, 13, 616-630.

3. Nana, A.W.; Yang, P.M.; Lin, H.Y. Overview of Transforming Growth Factor beta Superfamily Involvement in Glioblastoma Initiation and Progression. Asian Pac. J. Cancer Prev. 2015, 16, 6813-6823. [CrossRef] [PubMed]

4. Shi, Y.; Massague, J. Mechanisms of TGF- $\beta$ signaling from cell membrane to the nucleus. Cell 2003, 113, 685-700. [CrossRef]

5. Ikushima, H.; Miyazono, K. Cellular context-dependent "colors" of transforming growth factor- $\beta$ signaling. Cancer Sci. 2010, 101, 306-312. [CrossRef] [PubMed]

6. Iwatsuki, M.; Mimori, K.; Yokobori, T.; Ishi, H.; Beppu, T.; Nakamori, S.; Baba, H.; Mori, M. Epithelial-mesenchymal transition in cancer development and its clinical significance. Cancer Sci. 2010, 101, 293-299. [CrossRef] [PubMed]

7. Padua, D.; Massague, J. Roles of TGF $\beta$ in metastasis. Cell Res. 2009, 19, 89-102. [CrossRef] [PubMed]

8. Fabregat, I.; Fernando, J.; Mainez, J.; Sancho, P. TGF- $\beta$ signaling in cancer treatment. Curr. Pharm. Des. 2014, 20, 2934-2947. [CrossRef] [PubMed]

9. Massagué, J. TGF $\beta$ in Cancer. Cell 2008, 134, 215-230. [CrossRef] [PubMed]

10. Ikushima, H.; Miyazono, K. TGF-beta signal transduction spreading to a wider field: A broad variety of mechanisms for context-dependent effects of TGF- $\beta$. Cell Tissue Res. 2012, 347, 37-49. [CrossRef] [PubMed] 
11. Levy, L.; Hill, C.S. Alterations in components of the TGF- $\beta$ superfamily signaling pathways in human cancer. Cytokine Growth Factor Rev. 2006, 17, 41-58. [CrossRef] [PubMed]

12. O'Leary, K.; Shia, A.; Cavicchioli, F.; Haley, V.; Comino, A.; Merlano, M.; Mauri, F.; Walter, K.; Lackner, M.; Wischnewsky, M.B.; et al. Identification of Endoglin as an epigenetically regulated tumour-suppressor gene in lung cancer. Br. J. Cancer 2015, 113, 970-978. [CrossRef] [PubMed]

13. Kuo, K.K.; Jian, S.F.; Li, Y.J.; Wan, S.W.; Weng, C.C.; Fang, K.; Wu, D.C.; Cheng, K.H. Epigenetic inactivation of transforming growth factor-beta1 target gene HEYL, a novel tumor suppressor, is involved in the P53-induced apoptotic pathway in hepatocellular carcinoma. Hepatol. Res. 2015, 45, 782-793. [CrossRef] [PubMed]

14. Sato, M.; Kadota, M.; Tang, B.; Yang, H.H.; Yang, Y.A.; Shan, M.; Weng, J.; Welsh, M.A.; Flanders, K.C.; Nagano, Y.; et al. An integrated genomic approach identifies persistent tumor suppressive effects of transforming growth factor- $\beta$ in human breast cancer. Breast Cancer Res. 2014. [CrossRef] [PubMed]

15. Ciftci, R.; Tas, F.; Yasasever, C.T.; Aksit, E.; Karabulut, S.; Sen, F.; Keskin, S.; Kilic, L.; Yildiz, I.; Bozbey, H.U.; et al. High serum transforming growth factor $\beta 1$ (TGFB1) level predicts better survival in breast cancer. Tumour Biol. 2014, 35, 6941-6948. [CrossRef] [PubMed]

16. Lee, I.H.; Sohn, M.; Lim, H.J.; Yoon, S.; Oh, H.; Shin, S.; Shin, J.H.; Oh, S.H.; Kim, J.; Lee, D.K.; et al. Ahnak functions as a tumor suppressor via modulation of TGF $\beta /$ Smad signaling pathway. Oncogene 2014, 33, 4675-4684. [CrossRef] [PubMed]

17. Polyak, K.; Weinberg, R.A. Transitions between epithelial and mesenchymal states: Acquisition of malignant and stem cell traits. Nat. Rev. Cancer 2009, 9, 265-273. [CrossRef] [PubMed]

18. Miyazono, K. Transforming growth factor-beta signaling in epithelial-mesenchymal transition and progression of cancer. Proc. Jpn. Acad. Ser. B Phys. Biol. Sci. 2009, 85, 314-323. [CrossRef] [PubMed]

19. De Craene, B.; Berx, G. Regulatory networks defining EMT during cancer initiation and progression. Nat. Rev. Cancer 2013, 13, 97-110. [CrossRef] [PubMed]

20. Ma, G.F.; Miao, Q.; Zeng, X.Q.; Luo, T.C.; Ma, L.L.; Liu, Y.M.; Lian, J.J.; Gao, H.; Chen, S.Y. Transforming growth factor- $\beta 1$ and $-\beta 2$ in gastric precancer and cancer and roles in tumor-cell interactions with peripheral blood mononuclear cells in vitro. PLoS ONE 2013, 8, e54249. [CrossRef] [PubMed]

21. Kitamura, K.; Kasuya, K.; Tsuchida, A.; Mimuro, A.; Inoue, K.; Aoki, T.; Aoki, T.; Koyanagi, Y. Immunohistochemical analysis of transforming growth factor $\beta$ in gallbladder cancer. Oncol. Rep. 2003, 10, 327-332. [CrossRef] [PubMed]

22. Fukai, Y.; Fukuchi, M.; Masuda, N.; Osawa, H.; Kato, H.; Nakajima, T.; Kuwano, H. Reduced expression of transforming growth factor- $\beta$ receptors is an unfavorable prognostic factor in human esophageal squamous cell carcinoma. Int. J. Cancer. 2003, 104, 161-166. [CrossRef] [PubMed]

23. Abou-Shady, M.; Baer, H.U.; Friess, H.; Berberat, P.; Zimmermann, A.; Graber, H.; Gold, L.I.; Korc, M.; Buchler, M.W. Transforming growth factor betas and their signaling receptors in human hepatocellular carcinoma. Am. J. Surg. 1999, 177, 209-215. [CrossRef]

24. Tsushima, H.; Kawata, S.; Tamura, S.; Ito, N.; Shirai, Y.; Kiso, S.; Imai, Y.; Shimomukai, H.; Nomura, Y.; Matsuda, Y.; et al. High levels of transforming growth factor beta 1 in patients with colorectal cancer: Association with disease progression. Gastroenterology 1996, 110, 375-382. [CrossRef] [PubMed]

25. Friess, H.; Yamanaka, Y.; Buchler, M.; Ebert, M.; Beger, H.G.; Gold, L.I.; Korc, M. Enhanced expression of transforming growth factor beta isoforms in pancreatic cancer correlates with decreased survival. Gastroenterology 1993, 105, 1846-1856. [CrossRef]

26. Voon, D.C.; Wang, H.; Koo, J.K.; Chai, J.H.; Hor, Y.T.; Tan, T.Z.; Chu, Y.S.; Mori, S.; Ito, Y. EMT-induced stemness and tumorigenicity are fueled by the EGFR/Ras pathway. PLoS ONE 2013, 8, e70427. [CrossRef] [PubMed]

27. Liu, Z.; Li, Q.; Li, K.; Chen, L.; Li, W.; Hou, M.; Liu, T.; Yang, J.; Lindvall, C.; Bjorkholm, M.; et al. Telomerase reverse transcriptase promotes epithelial-mesenchymal transition and stem cell-like traits in cancer cells. Oncogene 2013, 32, 4203-4213. [CrossRef] [PubMed]

28. Sato, Y.; Harada, K.; Itatsu, K.; Ikeda, H.; Kakuda, Y.; Shimomura, S.; Ren, X.S.; Yoneda, N.; Sasaki, M.; Nakanuma, Y. Epithelial-mesenchymal transition induced by transforming growth factor- $\beta 1 /$ Snail activation aggravates invasive growth of cholangiocarcinoma. Am. J. Pathol. 2010, 177, 141-152. [CrossRef] [PubMed]

29. Yoo, H.J.; Yun, B.R.; Kwon, J.H.; Ahn, H.S.; Seol, M.A.; Lee, M.J.; Yu, G.R.; Yu, H.C.; Hong, B.; Choi, K.; et al. Genetic and expression alterations in association with the sarcomatous change of cholangiocarcinoma cells. Exp. Mol. Med. 2009, 41, 102-115. [CrossRef] [PubMed] 
30. Ween, M.P.; Oehler, M.K.; Ricciardelli, C. Transforming Growth Factor- $\beta$-Induced Protein (TGFBI)/( $\beta$ ig-H3): A Matrix Protein with Dual Functions in Ovarian Cancer. Int. J. Mol. Sci. 2012, 13, 10461-10477. [CrossRef] [PubMed]

31. Skonier, J.; Neubauer, M.; Madisen, L.; Bennett, K.; Plowman, G.D.; Purchio, A.F. cDNA cloning and sequence analysis of $\beta$ ig-h3, a novel gene induced in a human adenocarcinoma cell line after treatment with transforming growth factor- $\beta$. DNA Cell Biol. 1992, 11, 511-522. [CrossRef] [PubMed]

32. Han, K.E.; Choi, S.I.; Kim, T.I.; Maeng, Y.S.; Stulting, R.D.; Ji, Y.W.; Kim, E.K. Pathogenesis and treatments of TGFBI corneal dystrophies. Prog. Retin. Eye Res. 2016, 50, 67-88. [CrossRef] [PubMed]

33. Cha, D.R.; Kim, I.S.; Kang, Y.S.; Han, S.Y.; Han, K.H.; Shin, C.; Ji, Y.H.; Kim, N.H. Urinary concentration of transforming growth factor- $\beta$-inducible gene-h3( $\beta$ ig-h3) in patients with Type 2 diabetes mellitus. Diabet. Med. 2005, 22, 14-20. [CrossRef] [PubMed]

34. Li, C.; Lim, S.W.; Choi, B.S.; Lee, S.H.; Cha, J.H.; Kim, I.S.; Kim, J.; Yang, C.W. Inhibitory effect of pravastatin on transforming growth factor $\beta 1$-inducible gene $\mathrm{h} 3$ expression in a rat model of chronic cyclosporine nephropathy. Am. J. Nephrol. 2005, 25, 611-620. [CrossRef] [PubMed]

35. Yun, S.J.; Kim, M.O.; Kim, S.O.; Park, J.; Kwon, Y.K.; Kim, I.S.; Lee, E.H. Induction of TGF- $\beta$-inducible gene-h3 ( $\beta$ ig-h3) by TGF- $\beta 1$ in astrocytes: Implications for astrocyte response to brain injury. Brain Res. Mol. Brain Res. 2002, 107, 57-64. [CrossRef]

36. O’Brien, E.R.; Bennett, K.L.; Garvin, M.R.; Zderic, T.W.; Hinohara, T.; Simpson, J.B.; Kimura, T.; Nobuyoshi, M.; Mizgala, H.; Purchio, A.; et al. $\beta i g-h 3$, a transforming growth factor- $\beta$-inducible gene, is overexpressed in atherosclerotic and restenotic human vascular lesions. Arterioscler. Thromb. Vasc. Biol. 1996, 16, 576-584. [CrossRef] [PubMed]

37. Ozawa, D.; Yokobori, T.; Sohda, M.; Sakai, M.; Hara, K.; Honjo, H.; Kato, H.; Miyazaki, T.; Kuwano, H. TGFBI Expression in Cancer Stromal Cells is Associated with Poor Prognosis and Hematogenous Recurrence in Esophageal Squamous Cell Carcinoma. Ann. Surg. Oncol. 2016, 23, 282-289. [CrossRef] [PubMed]

38. Choi, S.I.; Maeng, Y.S.; Kim, K.S.; Kim, T.I.; Kim, E.K. Autophagy is induced by raptor degradation via the ubiquitin/proteasome system in granular corneal dystrophy type 2. Biochem. Biophys. Res. Commun. 2014, 450, 1505-1511. [CrossRef] [PubMed]

39. Choi, S.I.; Kim, E.K. Autophagy in granular corneal dystrophy type 2. Exp. Eye Res. 2016, 144, $14-21$. [CrossRef] [PubMed]

40. Choi, S.I.; Jin, J.Y.; Maeng, Y.S.; Kim, T.I.; Kim, E.K. TGF- $\beta$ regulates TGFBIp expression in corneal fibroblasts via miR-21, miR-181a, and Smad signaling. Biochem. Biophys. Res. Commun. 2016, 472, 150-155. [CrossRef] [PubMed]

41. Dokmanovic, M.; Chang, B.D.; Fang, J.; Roninson, I.B. Retinoid-induced growth arrest of breast carcinoma cells involves co-activation of multiple growth-inhibitory genes. Cancer Biol. Ther. 2002, 1, 24-27. [CrossRef] [PubMed]

42. Nam, E.J.; Sa, K.H.; You, D.W.; Cho, J.H.; Seo, J.S.; Han, S.W.; Park, J.Y.; Kim, S.I.; Kyung, H.S.; Kim, I.S.; et al. Up-regulated transforming growth factor $\beta$-inducible gene $\mathrm{h} 3$ in rheumatoid arthritis mediates adhesion and migration of synoviocytes through $\alpha \mathrm{v} \beta 3$ integrin: Regulation by cytokines. Arthritis Rheum. 2006, 54, 2734-2744. [CrossRef] [PubMed]

43. Gratchev, A.; Guillot, P.; Hakiy, N.; Politz, O.; Orfanos, C.E.; Schledzewski, K.; Goerdt, S. Alternatively activated macrophages differentially express fibronectin and its splice variants and the extracellular matrix protein BIG-H3. Scand. J. Immunol. 2001, 53, 386-392. [CrossRef] [PubMed]

44. Tumbarello, D.A.; Andrews, M.R.; Brenton, J.D. SPARC Regulates Transforming Growth Factor Beta Induced (TGFBI) Extracellular Matrix Deposition and Paclitaxel Response in Ovarian Cancer Cells. PLoS ONE 2016, 11, e0162698. [CrossRef] [PubMed]

45. Choi, S.I.; Lee, E.; Jeong, J.B.; Akuzum, B.; Maeng, Y.S.; Kim, T.I.; Kim, E.K. 4-Phenylbutyric acid reduces mutant-TGFBIp levels and ER stress through activation of ERAD pathway in corneal fibroblasts of granular corneal dystrophy type 2. Biochem. Biophys. Res. Commun. 2016, 477, 841-846. [CrossRef] [PubMed]

46. Hung, M.S.; Chen, I.C.; You, L.; Jablons, D.M.; Li, Y.C.; Mao, J.H.; Xu, Z.; Lung, J.H.; Yang, C.T.; Liu, S.T. Knockdown of cullin 4A inhibits growth and increases chemosensitivity in lung cancer cells. J. Cell. Mol. Med. 2016, 20, 1295-1306. [CrossRef] [PubMed] 
47. Zhang, Y.; Wen, G.; Shao, G.; Wang, C.; Lin, C.; Fang, H.; Balajee, A.S.; Bhagat, G.; Hei, T.K.; Zhao, Y. TGFBI deficiency predisposes mice to spontaneous tumor development. Cancer Res. 2009, 69, 37-44. [CrossRef] [PubMed]

48. Han, B.; Cai, H.; Chen, Y.; Hu, B.; Luo, H.; Wu, Y.; Wu, J. The role of TGFBI (ßig-H3) in gastrointestinal tract tumorigenesis. Mol. Cancer 2015. [CrossRef] [PubMed]

49. Nishimura, K.; Semba, S.; Aoyagi, K.; Sasaki, H.; Yokozaki, H. Mesenchymal stem cells provide an advantageous tumor microenvironment for the restoration of cancer stem cells. Pathobiology 2012, 79, 290-306. [CrossRef] [PubMed]

50. Turtoi, A.; Musmeci, D.; Wang, Y.; Dumont, B.; Somja, J.; Bevilacqua, G.; de Pauw, E.; Delvenne, P.; Castronovo, V. Identification of novel accessible proteins bearing diagnostic and therapeutic potential in human pancreatic ductal adenocarcinoma. J. Proteome Res. 2011, 10, 4302-4313. [CrossRef] [PubMed]

51. Patry, M.; Teinturier, R.; Goehrig, D.; Zetu, C.; Ripoche, D.; Kim, I.S.; Bertolino, P.; Hennino, A. ßig-h3 Represses T-Cell Activation in Type 1 Diabetes. Diabetes 2015, 64, 4212-4219. [CrossRef] [PubMed]

52. Zhu, J.; Nie, S.; Wu, J.; Lubman, D.M. Target proteomic profiling of frozen pancreatic CD24+ adenocarcinoma tissues by immuno-laser capture microdissection and nano-LC-MS/MS. J. Proteome Res. 2013, 12, 2791-2804. [CrossRef] [PubMed]

53. Jinawath, N.; Chamgramol, Y.; Furukawa, Y.; Obama, K.; Tsunoda, T.; Sripa, B.; Pairojkul, C.; Nakamura, Y. Comparison of gene expression profiles between Opisthorchis viverrini and non-Opisthorchis viverrini associated human intrahepatic cholangiocarcinoma. Hepatology 2006, 44, 1025-1038. [CrossRef] [PubMed]

54. Buckhaults, P.; Rago, C.; Croix, B.S.; Romans, K.E.; Saha, S.; Zhang, L.; Vogelstein, B.; Kinzler, K.W. Secreted and cell surface genes expressed in benign and malignant colorectal tumors. Cancer Res. 2001, 61, 6996-7001. [PubMed]

55. Turtoi, A.; Blomme, A.; Debois, D.; Somja, J.; Delvaux, D.; Patsos, G.; di Valentin, E.; Peulen, O.; Mutijima, E.N.; de Pauw, E.; et al. Organized proteomic heterogeneity in colorectal cancer liver metastases and implications for therapies. Hepatology 2014, 59, 924-934. [CrossRef] [PubMed]

56. Ma, C.; Rong, Y.; Radiloff, D.R.; Datto, M.B.; Centeno, B.; Bao, S.; Cheng, A.W.; Lin, F.; Jiang, S.; Yeatman, T.J.; et al. Extracellular matrix protein $\beta$ ig-h3/TGFBI promotes metastasis of colon cancer by enhancing cell extravasation. Genes Dev. 2008, 22, 308-321. [CrossRef] [PubMed]

57. Fakhrai, H.; Mantil, J.C.; Liu, L.; Nicholson, G.L.; Murphy-Satter, C.S.; Ruppert, J.; Shawler, D.L. Phase I clinical trial of a TGF- $\beta$ antisense-modified tumor cell vaccine in patients with advanced glioma. Cancer Gene Ther. 2006, 13, 1052-1060. [CrossRef] [PubMed]

58. Melisi, D.; Ishiyama, S.; Sclabas, G.M.; Fleming, J.B.; Xia, Q.; Tortora, G.; Abbruzzese, J.L.; Chiao, P.J. LY2109761, a novel transforming growth factor $\beta$ receptor type I and type II dual inhibitor, as a therapeutic approach to suppressing pancreatic cancer metastasis. Mol. Cancer Ther. 2008, 7, 829-840. [CrossRef] [PubMed]

59. Nemunaitis, J.; Dillman, R.O.; Schwarzenberger, P.O.; Senzer, N.; Cunningham, C.; Cutler, J.; Tong, A.; Kumar, P.; Pappen, B.; Hamilton, C.; et al. Phase II study of belagenpumatucel-L, a transforming growth factor beta-2 antisense gene-modified allogeneic tumor cell vaccine in non-small-cell lung cancer. J. Clin. Oncol. 2006, 24, 4721-4730. [CrossRef] [PubMed]

60. Giannelli, G.; Mikulits, W.; Dooley, S.; Fabregat, I.; Moustakas, A.; Dijke, P.t.; Portincasa, P.; Winter, P.; Janssen, R.; Leporatti, S.; et al. The rationale for targeting TGF- $\beta$ in chronic liver diseases. Eur. J. Clin. Investig. 2016, 46, 349-361. [CrossRef] [PubMed]

61. Giaccone, G.; Bazhenova, L.A.; Nemunaitis, J.; Tan, M.; Juhasz, E.; Ramlau, R.; van den Heuvel, M.M.; Lal, R.; Kloecker, G.H.; Eaton, K.D.; et al. A phase III study of belagenpumatucel-L, an allogeneic tumour cell vaccine, as maintenance therapy for non-small cell lung cancer. Eur. J. Cancer 2015, 51, 2321-2329. [CrossRef] [PubMed]

62. Morris, J.C.; Tan, A.R.; Olencki, T.E.; Shapiro, G.I.; Dezube, B.J.; Reiss, M.; Hsu, F.J.; Berzofsky, J.A.; Lawrence, D.P. Phase I study of GC1008 (fresolimumab): A human anti-transforming growth factor-beta (TGF $\beta$ ) monoclonal antibody in patients with advanced malignant melanoma or renal cell carcinoma. PLoS ONE 2014, 9, e90353. [CrossRef] [PubMed]

63. Ahmed, A.A.; Mills, A.D.; Ibrahim, A.E.; Temple, J.; Blenkiron, C.; Vias, M.; Massie, C.E.; Iyer, N.G.; McGeoch, A.; Crawford, R.; et al. The extracellular matrix protein TGFBI induces microtubule stabilization and sensitizes ovarian cancers to paclitaxel. Cancer Cell 2007, 12, 514-527. [CrossRef] [PubMed] 
64. Irigoyen, M.; Pajares, M.J.; Agorreta, J.; Ponz-Sarvise, M.; Salvo, E.; Lozano, M.D.; Pio, R.; Gil-Bazo, I.; Rouzaut, A. TGFBI expression is associated with a better response to chemotherapy in NSCLC. Mol. Cancer 2010. [CrossRef] [PubMed]

65. Nummela, P.; Lammi, J.; Soikkeli, J.; Saksela, O.; Laakkonen, P.; Holtta, E. Transforming growth factor beta-induced (TGFBI) is an anti-adhesive protein regulating the invasive growth of melanoma cells. Am. J. Pathol. 2012, 180, 1663-1674. [CrossRef] [PubMed]

66. Wen, G.; Partridge, M.A.; Li, B.; Hong, M.; Liao, W.; Cheng, S.K.; Zhao, Y.; Calaf, G.M.; Liu, T.; Zhou, J.; et al. TGFBI expression reduces in vitro and in vivo metastatic potential of lung and breast tumor cells. Cancer Lett. 2011, 308, 23-32. [CrossRef] [PubMed]

67. Li, B.; Wen, G.; Zhao, Y.; Tong, J.; Hei, T.K. The role of TGFBI in mesothelioma and breast cancer: Association with tumor suppression. BMC Cancer 2012, 12, 239. [CrossRef] [PubMed]

(C) 2017 by the authors; licensee MDPI, Basel, Switzerland. This article is an open access article distributed under the terms and conditions of the Creative Commons Attribution (CC-BY) license (http://creativecommons.org/licenses/by/4.0/). 